DOI: https://dx.doi.org/10.33289/IJRPC.11.1.2021.11(19)

\title{
A REVIEW ON BIOSIMILARS A WHEEL OF FORTUNE FOR INDIAN PHARMA INDUSTRIES
}

\author{
PS. Rishika, Swarupa Arvapalli", A. Vaishnavi, \\ Syeda Jabeen, B. Karunakar and JVC. Sharma \\ Joginpally B.R. Pharmacy College, Moinabad, \\ Hyderabad, Telangana, India-500 075.
}

\begin{abstract}
A biosimilar is an organic product that is endorsed in view of a demonstrating that it is exceptionally like a FDA approved natural product. They are practically identical to generics as in they are endorsed substitutes for particular bio-built treatments, or biologics. Thus, biosimilars are "comparable yet not the same " or at the end of the day biosimilars are "the twin yet not the clone" to the first biologic pioneer item. The barriers with biosimilar are that, the two biosimilar have a different beginning, have identical therapeutic effect, may additionally have different side-effects and for this reason require thorough testing. The European Medicines Agency (EMA) turned into the principal administrative office to affirm a biosimilar. The Indian generics in industry got its first massive break in 1984, when the US surpassed what is referred to as Hatch-Waxman act. Biosimilars market place in India presently includes eight biosimilars. India has effectively ventured out to tap the rising open door in the biosimilars space. Main aim of biosimilar offers guaranteed increase in patient access to the biological therapy and health care cost. In India biosimilar has engrossed large investments in the areas of research, clinical trials and manufacturing.
\end{abstract}

Keywords: Biosimilars, Generics, Hatch- Waxmann act, FDA-approved natural product.

\section{INTRODUCTION}

Biopharmaceutical drugs have turned into cutting edge of pharmacotherapy in the health care. These include proteins got from recombinant DNA innovation and hybridoma method $^{1}$. Living creatures, for example plant and creature cells, microbes, infections and yeast are utilized for the generation of biopharmaceuticals ${ }^{2}$. Biopharmaceuticals can possibly reach up to half partake in worldwide pharmaceutical market sector in the following few years ${ }^{3}$. The expiry of patent insurance of numerous biopharmaceuticals has started the improvement of a class of option variants of pioneer biopharmaceuticals known as biosimilars. The expression of biosimilar is like "take after on biologics" is more mainstream in the American Connection ${ }^{4}$. A biosimilar is an organic product that is endorsed in view of a demonstrating that is exceptionally like a FDA approved natural product, and has no clinically significant contrasts regarding security and adequacy from the reference product ${ }^{5}$. An interchangeable natural product is biosimilar to a FDA $\square$ affirmed reference product and meets extra measures for compatibility. A compatible organic product might be substituted for the reference product by a drug specialist without the intercession of the social insurance supplier who endorsed the reference product ${ }^{6}$. They are practically identical to generics as in they are endorsed substitutes for particular bio built treatments, or biologics. At the same time generics are particular concotion duplicates of the small particle therapies they supplant, biosimilars include just the restoratively dynamic segment of larger molecule biologics. Biosimilars are expansive atom treatments that are produced through organic procedures in alleged bio reactors containing specific biological systems. In that capacity, they are harder to fabricate and require a more 
noteworthy arrangement of specialized skill ${ }^{7}$. Biologics, considered one of the quickest developing segments of the pharmaceutical sector, has acquainted numerous new medicines with life threatening and uncommon ailments. Thus, biosimilars are "comparable yet not the same" or at the end of the day biosimilars are "the twin yet not the same clone" to the first biologic pioneer item. Hence the field of biosimilars presents a few critical difficulties, including ${ }^{8}$.

1. Verification of the likeness,

2. The compatibility of biosimilars and trendsetter products,

3. The conceivable requirement for special naming to separate the different biopharmaceutical products.

4. Administrative structure.

5. Commercial open doors and in addition rules to help makers in item advancement.

6. Intellectual property rights.

7. Public well being.
An emphasis point in the pharmaceutical business has lingered with the endorsement of Hospira's biosimilar adaptation of remicade in Europe and the ensuing endorsement in the US. Of its first biosimilar, Novartis Zarxio ${ }^{9}$. In this way the industry has experienced patent precipices because of bland adaptations of little atom drugs hitting the business sector, with biologics staying very much ensured because of absence of suitable endorsement rules $^{10}$. The barriers with biosimilar are that, the two biosimilars have a different beginning, the two biosimilars may also have identical therapeutic effect, may additionally have different side effects and for this reason require thorough testing ${ }^{11}$.

The main reason of biosimilar drug development is the expiry of patent protection for lots biological medicines. (Table 1$)^{12,14}$.

\begin{tabular}{|c|c|c|c|c|}
\hline PRODUCTS & BIOPHARMACEUTICALS & INDICATION & $\begin{array}{c}\text { US PATENT } \\
\text { STATUS }\end{array}$ & EU PATENT STATUS \\
\hline Neutropin(somatropin) & Genetech & Growth disorder & Expired & Expired \\
\hline $\begin{array}{c}\text { Abbokinase } \\
\text { (EuduraseUrokunase) }\end{array}$ & Abbott & Ischemic events & Expired & Expired \\
\hline $\begin{array}{c}\text { Humulin } \\
\text { (Recombinant insulin) }\end{array}$ & Ali lily & Diabetes & Expired & Expired \\
\hline $\begin{array}{c}\text { Ceredas (Algucerase) } \\
\text { Streptase(Streptokinase) }\end{array}$ & Astra Zenera & Gaucher disease & Expired & Expired \\
\hline $\begin{array}{c}\text { Epogen,procrit,EPRES } \\
\text { (Erythropoietin) }\end{array}$ & Amgen & Anemice & Expired & Expired \\
\hline $\begin{array}{c}\text { Neorecormon } \\
\text { (Erythropoietin) }\end{array}$ & Roche & Anemia & Na & Na \\
\hline $\begin{array}{c}\text { Serotim(Somatropin) } \\
\text { Humatrope } \\
\text { (SOMATROPIN) }\end{array}$ & Eli lily & Aids wasting & Expired & Expired \\
\hline $\begin{array}{c}\text { Proleuckin(IL2) } \\
\text { Chiron }\end{array}$ & Gaucher disease \\
\hline $\begin{array}{c}\text { Neupogen(Filgrastim } \\
\text { GCSF }\end{array}$ & Expired & Expired \\
\hline
\end{tabular}

CDSCO forthwith said that the reference biologic can be licensed in complete ICH county (i.e, Japan, US, Canada, Switzerland), the reference biologic is not marketed in India ${ }^{15}$. Biosimilar industry has several advantages and disadvantages ${ }^{16}$.

\section{ADVANTAGES}

- Low cost and similar effectiveness of the original product.

- Limited lime is required to market than the original product.
- High chance of return of investment (ROI) than the new product R\&D.

- Discount in expensive healthcare treatment. 
- Large financial support is required due to rising regulatory requirements.

- According to consumers cost of biosimilar products are comparatively higher than the small molecule generic which is heavy reduction than the original product.

- Lack of understanding and reliability of industry.

\section{HISTORY}

In the 9 years since the European Medicine Agency (EMA) turned into the principal administrative office to affirm a biosimilar, more than 20 biosimilar items have been endorsed in Europe, and some of these biosimilars have additionally been affirmed as biosimilars in Australia, Japan and Canada. In the United states (US), the Food and Drug Administration (FDA) is relied upon to endorse its first biosimilar this year. The US, Japan, Australia, and Europe or ensuing section biologics (SEBs) in Canada, are created to duplicate a reference item yet have not been subjected to no holds barred similar studies with that reference item to meet the same endorsement norms as in the very controlled markets $^{17,18}$.

\section{Biosimilars in India}

The Indian generics in industry got its first massive break in 1984, when the US surpassed what is referred to as Hatch Waxman act. With this legislation, the United states streamlined the non-precise endorsements alongside those lines making it much less demanding for non-specific organizations to contend the US drug market ${ }^{19}$.

India is known for manufacturer of small molecule of active pharmaceutical components (APIs) for western pharmaceutical groups, particularly inside the generics quarter. However, India's contract production market is emerging three times to charge of the worldwide agreement marketplace 20,21 .

On 28th march 2016 central drugs standard control organization delivered new guidance for biosimilar developers as new biosimilar attain to marketplace earlier than other regions, and India's regulators should try to develop more precise steering on post marketing studies ${ }^{22}$.

Biosimilars market place in India presently includes eight biosimilars along with one for AbbVie's blockbuster Humira and two biosimilars for Roche's breast cancer remedy. Herceptin(trastuzumab), which are not authorized in every other country. Monoclonal antibodies (MAB) play a chief position in chemotherapy, so most of the biosimilar entrepreneurs are focused on the production $\mathrm{MAB}^{23}$.

Indian companies marketing biosimilars in India (Table 2$)^{24}$.

\begin{tabular}{|c|c|c|}
\hline Company(location) & Product description & Biosimilar \\
\hline Dr Reddy's lab(Hyderabad) & $\begin{array}{c}\text { Filgrastim (recombinant } \\
\text { granolocyte-macrophage } \\
\text { colony stimulating factor,GCSF) }\end{array}$ & Grafeel \\
\hline $\begin{array}{c}\text { Intas } \\
\text { (Ahmedabad) }\end{array}$ & $\begin{array}{c}\text { Filgrastim( recombinant GCSF) } \\
\text { PEGylated GCSF) }\end{array}$ & $\begin{array}{c}\text { Neukine } \\
\text { Neupeg }\end{array}$ \\
\hline $\begin{array}{c}\text { Shantha Biotech/Merieux } \\
\text { Alliance (Hyderabad) }\end{array}$ & $\begin{array}{c}\text { Recombinant Streptokinase } \\
\text { Recombinant erythropoietin }\end{array}$ & $\begin{array}{c}\text { Shankinase } \\
\text { Shanpoietin }\end{array}$ \\
\hline $\begin{array}{c}\text { Reliance life sciences } \\
\text { (Mumbai) }\end{array}$ & $\begin{array}{c}\text { Recombinant erythropoietin } \\
\text { Recombinant GCSF }\end{array}$ & $\begin{array}{c}\text { Relipoietin } \\
\text { ReliGrast }\end{array}$ \\
\hline $\begin{array}{c}\text { Wockhardt } \\
\text { (Mumbai) }\end{array}$ & $\begin{array}{c}\text { Recombinant erythropoietin } \\
\text { Recombinant Insulin }\end{array}$ & $\begin{array}{c}\text { Wepox } \\
\text { Wosulin }\end{array}$ \\
\hline $\begin{array}{c}\text { Biocontainment } \\
\text { (Bangalore) }\end{array}$ & $\begin{array}{c}\text { Recombinant Human } \\
\text { Erythropoietin }\end{array}$ \\
& $\begin{array}{c}\text { Filgrastim, recombinant GCSF } \\
\text { Recombinant Streptokinase } \\
\text { biosimilar } \\
\text { Recombinant human insulin }\end{array}$ & $\begin{array}{c}\text { Eripro } \\
\text { Nufil } \\
\text { Myokinase } \\
\text { Insugen }\end{array}$ \\
\hline
\end{tabular}

There are 25 Indian biosimilars industry marketing close to 50 products in the Indian market and few of these in some unregulated markets now the market is shifted towards diseases such as cardiac, diabetic and oncology due to its complex biotech drug increase number of tertiary care hospital 
resulted increase practice of biotech products $^{25}$

\section{CHALLENGES}

Comparative biologics are created through consecutive procedure to show the compatibility by broad characterization examines uncovering the atomic and quality ascribes concerning the reference biologic. Biosimilars must be efficiently built to coordinate the reference item. A similarly exercise must be taken after with the pioneer item at all levels of item advancement, including: physicochemical traits, organic action, pre-clinical invivo likeness, phase 1 PK and well being, and phase 3 viability and security $^{26,27}$.

Stepping stones for Indian biosimilars (India)

1. Market sector to physicians serving the rising white collar class.

2. Build up clear pathway for administrative endorsement of products.

3. Enormous opportunity for interest in Indian market sector.

4. Set up partnerships with global industry pioneers.

5. Fare to unregulated and semi regulated nations.

1. Market sector to physicians serving the rising white collar class

As new white collar class keeps on rising in India and other creating economies, interest for high quality, reasonably estimated biosimilars product is prone to increment.

2. Build up clear pathway for administrative endorsement of products

Straightforward endorsement procedure will expand product quality and decline and ideal opportunity to advertise for reasonable and possibly life saving biosimilar products.

3. Enormous opportunity for interest in Indian market sector

The necessity of serious examination and clinical trial requests extensive scale venture for biosimilar industry.

4. Set up partnerships with global industry pioneers

Access to best in class labs, experience with rigors clinical trial and financing international pharmaceutical giants have much to offer India based market sector contestants.
5. Fare to unregulated and semi regulated nations

Because of less administrative obstacles, creating nations are the most appealing fair opportunities in the transient ${ }^{28-32}$.

\section{CONCLUSION}

Main aim of biosimilar offers guaranteed increase in patient access to the biological therapy and health care cost. In India biosimilar has engrossed large investments in the areas of research, clinical trails and manufacturing. They provide numerous expansion and investment opportunities for India and foreign player. The Indian government should ensure the instructions to improve quality control. Extra noteworthy coordinated attempt among western and Indian groups implies cultivating an unusual degree of association between the two. In any case, the outcome-new quality products that are available to more people for much less might be justified irrespective of the exertion.

\section{REFERENCES}

1. Professor Paul J Declerckphd. Biologicals and biosimilars; a review of the science and its implications, generics and biosimilarsintitative $(\mathrm{GaBl}$ Journal). 2012;1(1);136. available from https://gabijournal.net/biologicals- and -biosimilars a review of the science and-its implications.html.

2. Crommelin DJ, Storm G, Verrjik R, de Leede $L$, Jiskoot $W$ and Hennink WE. Shifting paradigms: biopharmaceuticals versus low molecular weight drugs. Int $\mathrm{J}$ pharma. 2003;266:3-16.

3. Blanchard A, Helene D Lorio and Robert Ford. what you need to know to succeed: key trends in Canada's biotech industry. insights, spring. 2010.

4. Nick C. The US biosimilar act: challenges facing regulatory approval. Pharm Med. 2012;26(3):145-152.

5. Follow on protein products; Regulatory And Scientific issues related to developing; [Last accessed on 2013 July 15; published on 2015 April 09] Available from: https://www.fda.gov/drugs/science research/research areas/ucm085854.htm

6. Approval pathway for biosimilar and interchangeable biological products public meeting; FDA;November 2-3 2010.FDA page on Approval pathway for biosimilar and interchangeable biological products public meeting.

7. Sensabaugh SM. Requirments for biosimilars and interchangeable biological 
drugs in the United states. Drug Inf J. 2011;45(2):155-62.

8. Bhupinder Singh sekhon, vikrantsaluja, biosimilars: an overview; 15th march 2011; dovepress volume 2011; from https://www.dovepress.com/biosimilars an overview reviewed article, BS.

9. FDA approves first biosimilar product Zarxio; FDA; March 6 2015. FDA page on FDA approves first biosimilar product Zarxio.

10. How biosimilars can impact pharma company valuations; forbes. September 21 2015. http://www. forbes. com/ sites/greatspeculations/2015.

11. Li J, yang C, Xia Y, Bertino A, Glaspy J and Robert's M. Thrombocytopenia caused by the development of antibodies to thrombopoietin. Blood. 2001;98:32418.

12. Schellekens $H$ and Ruff JC. Biogenerics: the off patent biotech products. Trends pharmacology sci. 2002;23:119-21.

13. Joshi SR. Biosimilar insulins are they really similar assoc physicians India. 2009;57:38-41.

14. Thomas TK. Patent for biosimilar drugs may be made mandatory. The Hindu business line. Available from https://www.thehindubusinessline.in/2008/ 05/06/stories/20080506531000.htm.

15. Biosimilar News: India issues a proposed guideline for biosimilars available form: http://www.biosimilarnews.com/india issuesa-proposed guideline for biosimilars.

16. India brand equity foundation: formula of success, emerging trends in biosimilars in India.

17. EMA guideline on similar biological medicinal products, October 30, 2005.available

from:http://www.ema.europa.eu/docs/en $\mathrm{Gb} /$ document - library/ scientific guideline/ 2009.

18. Hunecutt BJ, Gillespie E and woollett GR. clinical trial in the development of biosimilars. Future Considerations July 2015 volume.

19. Mossinghoff and Gerald. Overview of the Hatch Waxman Act and its impact on the drug development process. Food and drug law journal. 1999;54187-194.

20. Genazanni A. Biosimilar drugs. Concerns and opportunities. Bio drugs. 2007;21:351357.

21. Biosimilars in India news: Recent guidelines from India's CDSCO and a pending case on Biosimilar Trastuzumab. 2016.

22. Zachary brennan. India releases new biosimilar guidelines; 28 march 2016 regulatory affairs professionals society.

23. Killugudijayaramam. Indian companies marketing biosimilars in India, herceptin nature Biotechnology 28; 883-884. http://wwwnature.

com/mbt/journal/v28/n9/fig_,tab/nbt09108 83_T1.html.

24. India can emerge as a key player in biosimilarsegment;chemetechfoundation;p harma biotech. Available from http://www.chetech-online.com/P\&B/

Ramniwas_april13.html.

25. Leader B, Baca QJ, Golan DE. Protein therapeutics. A summary and pharmacological classification. Nat reviews drug Discovery.

26. Bio biotechnology industry facts 2009 . http://bio.org/speeches /pubs/er/statistics. asp.

27. Ledford $H$. Biosimilar drugs poised to penetrate market. nature. 2010.

28. Marshall SA, Lazar GA, Chirino AJ and Desjarlais JR. rational design and engineering of therapeutic proteins. Drug Discovery Today.

29. De groot AS and Scott DW. Immunogenicity of protein therapeutics. Trends Immunol. 2007;28:482-490.

30. Www.fda.gov.

31. Biosimilars by Sandoz: capturing the future opportunity, Ameet Mallik, Global Head, Sandoz biopharmaceuticals and oncology injectables.

32. WHO. Guidelines on evaluation of similar biotherapeutic products (SBPs)WHO; Geneva, Switzerland. 2009. 